\author{
Michał DULAK \\ Uniwersytet Jagielloński \\ michal.dulak@uj.edu.pl
}

\title{
FUNKCJONOWANIE MECHANIZMU WCZESNEGO OSTRZEGANIA W LATACH 2010-2016 I PERSPEKTYWY JEGO REFORMY
}

ABSTRACT The functioning of the Early Warning System in the years 2010-2016 and prospects for its reform

During the Convention on the future of Europe and subsequent intergovernmental conferences in 2003-2004 and 2007, high hopes were associated with the Early Warning System (EWS) in subsidiarity control procedures. Today, the main complaint formulated against EWS is its low efficiency, and at least its unused potential. Three executions of the yellow card procedure and the failure to run the orange card procedure seems to confirm the complaint. The results of institutional and statistical research presented in the article confirm that EWS instruments, such as reasoned opinions and the mechanisms of yellow and orange cards lose their attractiveness over more flexible instruments such as political dialogue with the European Commission and the so called contribution tool within the relation with the European Parliament. The reason for this is the difficulty in obtaining the required number of votes by national parliaments, but also the lack of uniform criteria for examining the principle of subsidiarity within national legislatures. The article also presents current debate on improving the EWS mechanism and introducing new procedures such as the "green card".

Keywords: early warning system, subsidiarity, national parliaments, reasoned opinions, contributions

Słowa kluczowe: mechanizm wczesnego ostrzegania, subsydiarność, parlamenty narodowe, uzasadnione opinie, „żółta kartka”, „pomarańczowa kartka”, „zielona kartka”, przyczynki 


\section{WSTĘP}

Mechanizm wczesnego ostrzegania (Early Warning System, EWS) ustanowiony został dzięki zmianom wprowadzonym przez traktat z Lizbony do przepisów Traktatu o Unii Europejskiej i Traktatu ustanawiającego Wspólnoty Europejskie ${ }^{1}$. Tym samym parlamentom narodowym państw członkowskich zapewniono większy niż dotychczas wpływ na proces legislacyjny w UE. Dopuszczenie aktywności krajowych legislatur bezpośrednio na poziomie ponadnarodowym, niejako z pominięciem rządów, stanowiło poważną korektę w systemie politycznym UE. Dlatego to z EWS, spośród wszystkich instrumentów kontroli parlamentarnej w sprawach unijnych i zaangażowania parlamentów narodowych w UE, wiązano największe nadzieje. Przemawiały za tym przesłanki teoretyczne, takie jak ograniczenie deficytu demokracji w UE, oraz praktyczne - systematyczne zwiększanie roli parlamentów państw członkowskich od traktatu z Maastricht.

Wydaje się jednak, że po prawie dziewięciu latach od wejścia w życie traktatu z Lizbony EWS nie spełniło pokładanych w nim oczekiwań. Procedurę „żółtej kartki” uruchomiono trzykrotnie, podczas gdy mocniejszej procedury, „pomarańczowej kartki”, która wymagałaby wycofania wniosku legislacyjnego przez Komisję Europejską (KE), nie wykorzystano ani razu. Z kolei w latach 2010-2016 uzasadnione opinie, których określona liczba uruchamia wspomniane procedury, zostały wydane jedynie do 349 projektów aktów prawnych przygotowanych przez KE. W tym samym okresie liczba przyjętych aktów prawnych wyniosła $2654^{2}$. Jeśli wszystkie projekty, do których parlamenty narodowe zgłosiły zastrzeżenia związane z nieprzestrzeganiem zasady pomocniczości, zostały przyjęte, to stanowiły one jedynie $13 \%$ wszystkich aktów ustawodawczych uchwalonych w UE. Zauważyć można natomiast tendencję do coraz częstszego korzystania przez parlamenty z bardziej elastycznych instrumentów wyrażania opinii odnośnie do projektów aktów ustawodawczych oraz innych dokumentów KE.

Celem artykułu jest przedstawienie i wyjaśnienie sposobu, w który parlamenty państw członkowskich wykorzystywały mechanizm wczesnego ostrzegania w latach 2010-2016 oraz jakie problemy w związku z tym się uwidoczniły ${ }^{3}$. Tak zdefiniowana problematyka wymaga odpowiedzi na pytania o to, w jakiej skali stosowane są uzasadnione opinie oraz mechanizmy „żółtej” i „pomarańczowej kartki”, a także czy parlamenty narodowe chętnie wykorzystują bardziej elastyczne instrumenty oddziaływania

Traktat z Lizbony zmieniajacy Traktat o Unii Europejskiej i Traktat ustanawiający Wspólnotę Europejską, Dz.U. UE 2007, C 306, s. 150-152.

2 Statystyki dotyczące aktów prawnych, Eur-Lex. Baza aktów prawnych Unii Europejskiej, [online] http://eur-lex.europa.eu/statistics/legislative-acts-statistics.html, 20 III 2018.

3 W ostatnim czasie do najciekawszych publikacji w tym temacie należą: M. Witkowska, Parlamenty narodowe jako podmioty integracji europejskiej z perspektywy reformowania Unii Europejskiej, [w:] taż [i in.], Podmioty integracji europejskiej z perspektywy reformowania Unii Europejskiej, Warszawa 2017, s. 15-36; taż, The Use of the Concept of Policy Networks in the Study of Relations Between National Parliaments and the EU Institutions, „Przegląd Europejski” 2016, nr 4, s. 57-73. 
na proces legislacyjny w UE, takie jak dialog polityczny z KE oraz składanie tzw. przyczynków (contributions) do Parlamentu Europejskiego (PE). Przy wykorzystaniu analizy instytucjonalno-prawnej $\mathrm{w}$ drugim i trzecim rozdziale zaprezentowane zostaną zasady funkcjonowania EWS oraz dialogu politycznego, a także wpływ tych mechanizmów na zachowanie parlamentów narodowych w UE. Analiza danych statystycznych umożliwi zaś pokazanie praktyki stosowania EWS w latach 2010-2016 i jej efektów. Takie wskaźniki, jak: liczba uzasadnionych opinii, liczba opinii w ramach dialogu politycznego i contributions, zróżnicowanie aktywności ze względu na izby parlamentów w danym państwie i rodzaj izby, pozwolą odpowiedzieć na postawione pytania badawcze. Artykuł zakończy zestawienie propozycji państw członkowskich, których celem jest usprawnienie EWS w przyszłości.

\section{1. „WIRTUALNA TRZECIA IZBA UE”“}

Ian Cooper, odwołując się do kompetencji przyznanych parlamentom narodowym przez traktat z Lizbony, nazwal je wirtualna trzecia izbą UE. Do sformułowania takiej tezy skłoniło go przede wszystkim ustanowienie EWS. Kompetencje do wydawania uzasadnionych opinii odnośnie do przestrzegania zasady pomocniczości przez dany projekt aktu ustawodawczego UE stworzyły nową płaszczyznę do deliberacji o ważnych sprawach politycznych Unii. Zaś konsekwencje uzasadnionych opinii, czyli procedury „żółtej” i „pomarańczowej kartki”, spowodowały, że parlamenty narodowe mogą wspólnie wypetniać funkcje izby ustawodawczej bez potrzeby spotykania się w przestrzenifizycznej.

Kontrola przestrzegania zasady pomocniczości jest jedną z kilku kompetencji parlamentów narodowych państw członkowskich przyznanych na mocy traktatu z Lizbo$n y^{6}$. Mechanizm wczesnego ostrzegania, czyli EWS, jest zaś częścią procedury kontroli przestrzegania zasady pomocniczości i dotyczy projektów aktów ustawodawczych UE. EWS ma więc szczególne znaczenie dla pozycji parlamentów narodowych, gdyż jako pierwszy umożliwia im bezpośrednie wpływanie na proces legislacyjny na poziomie unijnym.

Protokół nr $2 \mathrm{w}$ sprawie stosowania zasady pomocniczości i proporcjonalności, dołączony do traktatu z Lizbony, wspomnianą kontrolę przestrzegania zasady pomocniczości dzieli na dwa etapy. Pierwszym jest kontrola uprzednia (ex ante) projektów aktów prawnych pod kątem przestrzegania przez nie zasady pomocniczości, czyli właśnie mechanizm wczesnego ostrzegania. Kontrola w tej fazie przeprowadzana jest

4 I. Cooper, $A$ "Virtual Third Chamber" for the European Union? National Parliaments after the Treaty of Lisbon, „West European Politics” 2012, vol. 35, nr 3, s. 441-465, [online] https://doi.org/10.1080/ 01402382.2012.665735.

5 Tamże, s. 444.

6 J.J. Węc, Traktat lizboński. Polityczne aspekty reformy ustrojowej Unii Europejskiej w latach 2007-2009, Kraków 2011, s. 214-226; M. Dulak, Legitymizacja polskiej polityki europejskiej. Analiza systemowa, Kraków 2017, s. 83-96. 
bezpośrednio przez parlament narodowy (art. 4-7 Protokołu nr 2) i obejmuje wszystkie projekty aktów ustawodawczych, które krajowe legislatury otrzymują na podstawie przepisów Protokołu nr $1 \mathrm{w}$ sprawie roli parlamentów narodowych w Unii Europejskiej. Skutkiem kontroli ex ante może być zablokowanie procedury ustawodawczej.

Drugim etapem kontroli przestrzegania zasady pomocniczości jest kontrola następcza (expost). Odbywa się przed Trybunałem Sprawiedliwości UE (TS UE) na podstawie skarg składanych przez parlamenty narodowe oraz Komitet Regionów odnośnie do obowiązujących już aktów ustawodawczych. Przepisy regulujące procedurę zaskarżania aktów prawnych określane są w przypadku parlamentów przez krajowy porządek prawny. W przypadku Komitetu Regionów kompetencja skargowa ogranicza się jedynie do tych aktów ustawodawczych, do których zgodnie z Traktatem o funkcjonowaniu UE wymagana jest konsultacja tego organu (art. 8 Protokołu nr 2). Zatem kontrola ex post dotyczy tylko wybranych aktów ustawodawczych, a jej skutkiem może być delegalizacja danego aktu? .

EWS dotyczy tylko projektów aktów ustawodawczych UE, a więc uzasadnione opinie, które wydają parlamenty narodowe, również odnoszą się jedynie do przedmiotu tych dokumentów. Artykuł 2 Protokołu nr 1 definiuje „projekty aktów ustawodawczych" jako: wnioski KE, inicjatywy grupy państw członkowskich, inicjatywy PE, wnioski TS UE, zalecenia Europejskiego Banku Centralnego i wnioski Europejskiego Banku Inwestycyjnego, które mają na celu przyjęcie aktu ustawodawczego. Parlamenty narodowe otrzymują projekty aktów, których autorem jest KE, bezpośrednio od tej instytucji, równocześnie z PE i Radą Unii Europejskiej (RUE). Gdy parlament narodowy przyjmie uzasadnioną opinię do projektu otrzymanego od KE, przesyła ją bezpośrednio do tej instytucji. Procedura w przypadku dokumentów otrzymanych od PE jest analogiczna: PE przesyła projekty aktów ustawodawczych, których jest autorem, bezpośrednio do parlamentów narodowych. Dlatego też parlamenty narodowe przesyłają uzasadnione opinie, przyjęte do tego typu aktów, bezpośrednio do przewodniczącego PE. RUE z kolei przesyła parlamentom narodowym projekty aktów prawnych pochodzące od grupy państw członkowskich, TS UE, Europejskiego Banku Centralnego lub Europejskiego Banku Inwestycyjnego. W sytuacji, gdy parlament narodowy przyjmie uzasadnioną opinię do tej kategorii projektów aktów ustawodawczych, obowiązek przekazania tej opinii do instytucji, które wniosły dany projekt aktu ustawodawczego, ciąży na przewodniczącym RUE (art. 3 Protokołu nr 1).

Protokół nr 1 dołączony do TUE określa także czas na wyrażenie uzasadnionej opinii. Wynosi on osiem tygodni i jest liczony od momentu przekazania projektu aktu ustawodawczego parlamentom (art. 4). Po tym czasie projekt aktu ustawodawczego wpisywany jest do porządku obrad RUE i przechodzi do kolejnych etapów procesu legislacyjnego. Opisany termin wydłużono o 14 dni w stosunku do przepisów traktatu konstytucyjnego.

W uzasadnionych opiniach przesyłanych do przewodniczących PE, RUE i KE izby parlamentów narodowych wskazują powody uznania danego aktu ustawodawczego za

C. Mik, Pozycja prawna parlamentów narodowych $w$ Unii Europejskiej w świetle Traktatu z Lizbony, „Ruch Prawniczy, Ekonomiczny i Socjologiczny” 2010, z. 2, s. 80-81. 
niezgodny z zasadą pomocniczości. Następnie uzasadnione opinie przeliczane są na głosy; na podstawie art. 7 Protokołu nr 2 każdemu parlamentowi przyznano dwa głosy. W parlamentach dwuizbowych głosy podzielone są między izby. Obecnie w UE jest 13 parlamentów dwuizbowych oraz 15 parlamentów jednoizbowych. Jeżeli po przeliczeniu uzasadnionych opinii na głosy wyniosą one jedną trzecią głosów parlamentów narodowych (19 głosów) - lub jedną czwartą, gdy projekt dotyczy przestrzeni wolności, bezpieczeństwa i sprawiedliwości ( 14 głosów) - projektodawca zobligowany jest do ponownego przeanalizowania projektu aktu ustawodawczego. W rezultacie możliwe jest podtrzymanie, zmiana lub wycofanie projektu. Opisany mechanizm nazywany jest procedurą „żółtej kartki”.

Druga ze wspominanych procedur EWS, czyli procedura „pomarańczowej kartki", uruchamiana jest, gdy uzasadnione opinie wyrażą parlamenty narodowe posiadające zwykłą większość głosów i pod warunkiem, że zgłaszane będą one do projektu aktu ustawodawczego przyjmowanego w trybie zwykłej procedury ustawodawczej. Wówczas projekt poddawany jest ponownej analizie i po jej dokonaniu może zostać podtrzymany, zmieniony lub wycofany przez KE. Gdy Komisja zadecyduje o podtrzymaniu projektu, musi przedstawić opinię uzasadniającą. Następnie w toku zwykłej procedury ustawodawczej PE i RUE, rozpatrując taki akt ustawodawczy przed zakończeniem pierwszego czytania, ważą opinię KE i uzasadnione opinie parlamentów narodowych. Jeżeli 55\% członków RUE i większość deputowanych w PE uzna, że akt łamie zasadę pomocniczości, wstrzymywane są dalsze prace legislacyjne. Procedura „pomarańczowej kartki” jest silniejszym narzędziem kontroli ex ante niż procedura „żółtej kartki”.

Za uzupełnienie EWS można uznać nieformalne procedury dialogu politycznego między KE a parlamentami narodowymi oraz przyczynki przesyłane do PE'. Podwaliny pod te procedury położyła inicjatywa przewodniczącego KE José Manuela Barroso z 2006 r., na podstawie której KE miała przesyłać wszystkie nowe wnioski legislacyjne i dokumenty konsultacyjne bezpośrednio do krajowych legislatur ${ }^{10}$. Tym samym włączono parlamenty w obieg informacji unijnych jeszcze bez formalnej podstawy traktatowej ${ }^{11}$. Zainicjowano w ten sposób działający do dzisiaj tzw. dialog polityczny parlamentów krajowych z KE, w ramach którego Komisja odpowiada na zgłoszone do niej opinie i uwagi. Zarówno w przypadku KE, jak i PE wspomniane procedury zakładają przesłanie danej instytucji opinii do wybranego projektu aktu ustawodawczego,

8 Procedurę tę przewidywały także przepisy Protokołu $\mathrm{nr} 2 \mathrm{w}$ sprawie stosowania zasad pomocniczości i proporcjonalności dołączonego do traktatu konstytucyjnego. Zob. Traktat ustanawiający Konstytucje dla Europy, Dz.U. UE 2004, C 310/01, s. 213-215.

9 W przypadku PE opinie te nazywane są contribution i w oficjalnych dokumentach UE thumaczone jako „przyczynki”.

10 Komunikat Komisji do Rady Europejskiej. Plan osiagnięcia wyników dla Europy z myśla o obywatelach, Bruksela, 10 V 2006, COM(2006) 211 wersja ostateczna, s. 9-10.

11 Trwał wówczas tzw. okres refleksji po odrzuceniu traktatu konstytucyjnego. Zob. J.J. Węc, Spór o ksztatt instytucjonalny Wspólnot Europejskich i Unii Europejskiej 1950-2005. Między idea ponadnarodowości a wspótpraca międzyrządową. Analiza politologiczna, Kraków 2006, s. 481-489. 
zawierających poglądy izby dotyczące istotnych spraw politycznych, społecznych i gospodarczych, ale niepodnoszących kwestii zgodności z zasadą pomocniczości. Z tych względów w obu przypadkach są to instrumenty bardziej elastyczne niż uzasadnione opinie, a brak umocowania traktatowego sprawia, że nie rodzą żadnych skutków prawnych ${ }^{12}$. Jedyna różnica między dialogiem politycznym a przyczynkami przesyłanymi do PE polega na tym, że w konsekwencji praktyki ukształtowanej w ramach inicjatywy Barroso z 2006 r. KE zobligowana jest do przesyłania odpowiedzi, a więc swoistego wejścia w dialog z parlamentami krajowymi o sprawach legislacji unijnej ${ }^{13}$.

\section{PRAKTYKA I EFEKTY STOSOWANIA MECHANIZMU WCZESNEGO OSTRZEGANIA W LATACH 2010-2016}

Parlamenty narodowe przesłały w latach 2010-2016 więcej uzasadnionych opinii do PE (372) niż do KE (349), jednak różnica ta nie jest duża. Można więc uznać, że legislatury krajowe nie różnicują $\mathrm{w}$ istotny sposób obu instytucji unijnych, próbując w większym stopniu wpłynąć na kształt aktu ustawodawczego na etapie prac tylko w KE lub PE. Jak pokazuje wykres 1, w ujęciu rocznym również nie są dostrzegalne duże różnice. Należy jedynie zwrócić uwagę na spadek liczby uzasadnionych opinii w latach 2014 i 2015. Zjawisko to można tłumaczyć dwojako. Po pierwsze, w 2014 r. odbyły się wybory do PE i wyłoniono nowy skład KE. Aktywność polityczna parlamentów nie koncentrowała się więc na unijnym procesie legislacyjnym. Po drugie, w latach 2014 i 2015 zauważalny jest spadek nowych inicjatyw legislacyjnych $\mathrm{KE}^{14}$. Dane z 2016 r. pokazują jednak, że liczba uzasadnionych opinii przesyłanych do KE i PE wróciła do poziomu sprzed 2014 r. Aby stwierdzić, czy ta tendencja jest trwała, należy poczekać, by przekonać się, czy podobne wnioski popłyną z komunikatów KE na temat współpracy z parlamentami za rok 2017 i kolejne lata.

Interesujące jest zachowanie parlamentów w odniesieniu do stosowania dialogu politycznego z KE oraz przyczynków przesyłanych do PE (zob. wykres 2).

12 A. Grzelak, J. Łacny, Kontrola przestrzegania unijnej zasady pomocniczości przez parlamenty narodowe-pierwsze doświadczenia, „Zeszyty Prawnicze Biura Analiz Sejmowych” 2011, nr 4, s. 32.

Szerzej na temat wykorzystywania dialogu politycznego jako narzędzia tworzenia sieci politycznej współpracy z KE zob. M. Witkowska, The Use of the Concept..., s. 63-65.

14 W 2014 r. KE przedstawiła 29 nowych inicjatyw legislacyjnych, a w $2015-23$. W roku poprzedzającym wybory do PE, czyli 2013, liczba nowych inicjatyw legislacyjnych KE wyniosła 58. Por. European Commission, Annex to the Communication from the Commission to the European Parliament, the Council, the European Economic and Social Committee and the Committee of the Regions. Commission Work Programme 2013, Strasbourg, 29 VI 2012, COM(2012) 629 final; European Commission, Annexes to the Communication from the Commission to the European Parliament, the Council, the European Economic and Social Committee and the Committee of the Regions. Commission Work Programme 2014, Brussels, 22 X 2013, COM(2013) 739 final; European Commission, Annex to the Communication from the Commission to the European Parliament, the Council, the European Economic and Social Committee and the Committee of the Regions. Commission Work Programme 2015. A New Start, Strasbourg, 8 I 2015, $\operatorname{COM}(2014) 910$ final. 
Wykres 1. Liczba uzasadnionych opinii parlamentów narodowych przesłanych do KE i PE (2010-2016)

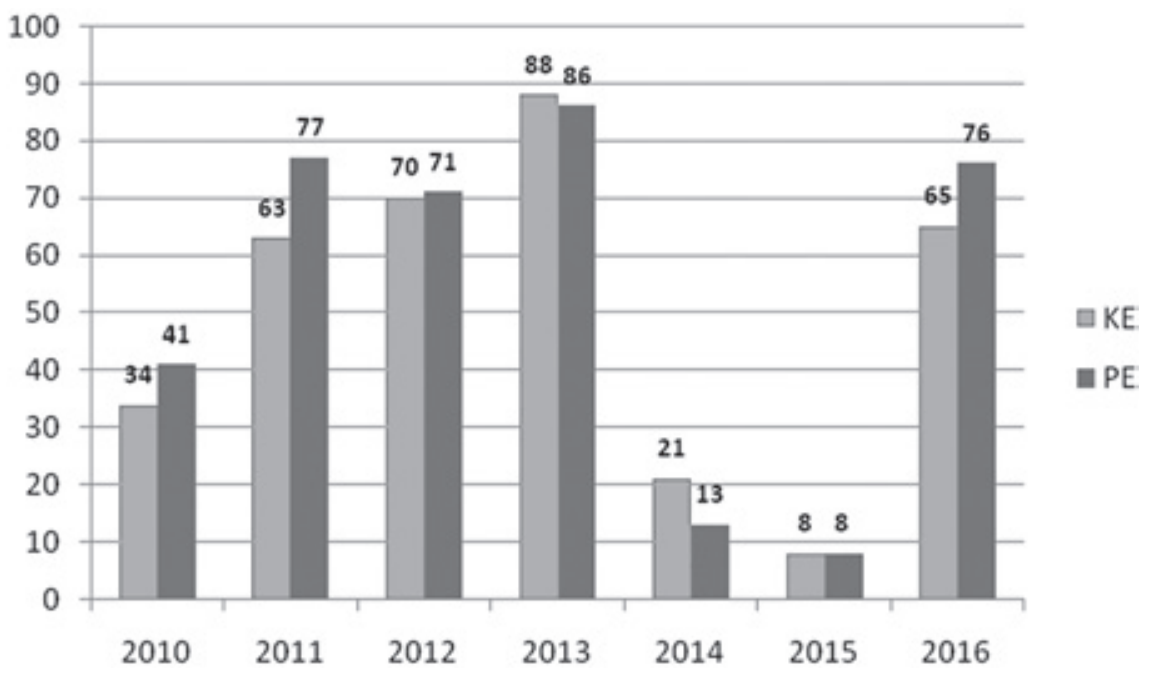

Źródło: opracowanie własne na podstawie: European Commission, Annual Reports on Relations with National Parliaments, [online] https://ec.europa.eu/info/annual-reports-relations-national-parliaments_ en, 1 III 2018; European Commision, Annual Reports on Subsidiarity and Proportionality, [online] http:// ec.europa.eu/dgs/secretariat_general/relations/relations_other/npo/subsidiarity_reports_en.htm, 1 III 2018; European Parliament, Annual Statistics for Subsidiarity Checks by National Parliaments, [online] http://www.europarl.europa.eu/relnatparl/en/about/subsidiarity.html, 1 III 2018.

Wykres 2. Opinie przesłane przez parlamenty narodowe w ramach dialogu politycznego z KE oraz przyczynki przesyłane do PE (2010-2016)

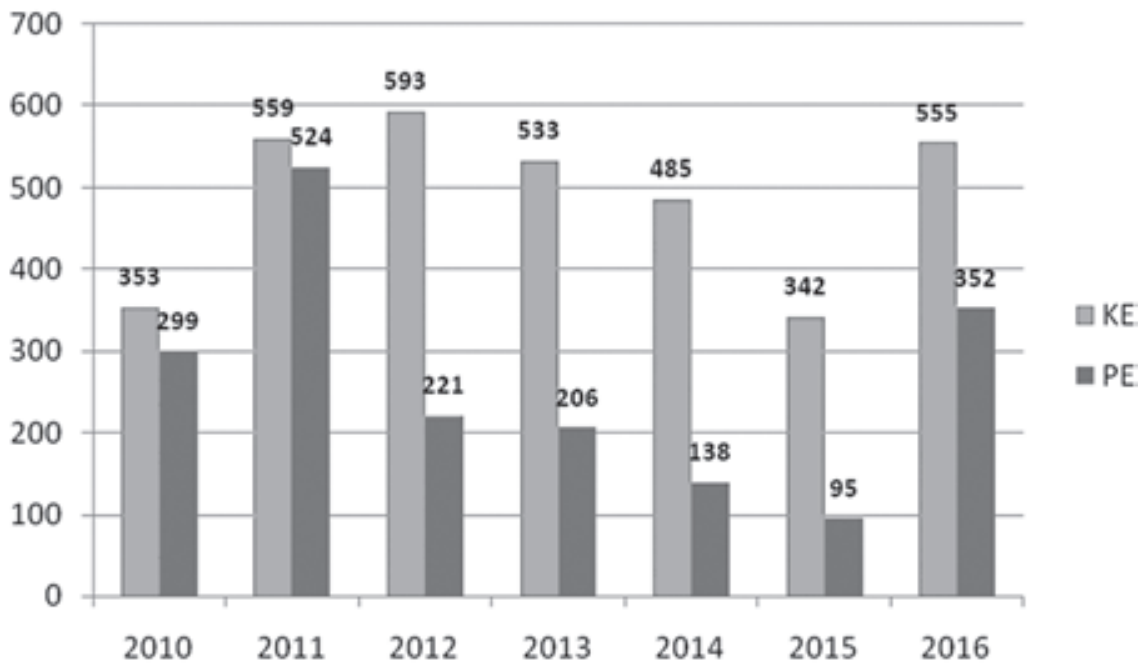

Źródło: opracowanie własne na podstawie: European Commission, Annual Reports on Relations...; European Commission, Annual Reports on Subsidiarity...; European Parliament, Annual Statistics for Subsidiarity Checks... 
Wyraźny spadek liczby przyczynków wysyłanych do PE po 2011 r. sugeruje, że formuła dialogu z KE jest bardziej atrakcyjna dla parlamentów krajowych, chociażby ze względu na informację zwrotną, którą otrzymują na temat swoich uwag. Ogólna liczba opinii w ramach dialogu politycznego oraz przyczynków w stosunku do uzasadnionych opinii pozwala zaś sformułować tezę, że parlamenty narodowe wykazują wolę oddziaływania na treść projektów aktów ustawodawczych w większym stopniu niż tylko pod kątem przestrzegania zasady subsydiarności. Inicjatywy takie, jak „zielona kartka”, które zostaną opisane w kolejnym rozdziale, wydają się do pewnego stopnia to potwierdzać.

Duża liczba projektów aktów prawnych UE, które spływają do parlamentów narodowych, wymaga ich sprawnej analizy i ewentualnego opracowania uzasadnionej opinii w ciągu ośmiu tygodni. Do tego z kolei potrzebne są zasoby w postaci odpowiednio dużej liczby parlamentarzystów oraz służb legislacyjnych z kancelarii parlamentarnych wspierających ich w pracy. W oczywisty sposób - co potwierdzają dane - lepiej przygotowane są do tego parlamenty dwuizbowe, każda z izb posiada bowiem swoją komisję ds. europejskich ${ }^{15}$. W latach 2010-2016 parlamenty dwuizbowe, których w UE jest 13, przesłały do KE i PE łącznie 431 uzasadnionych opinii, a także 3423 opinie w ramach dialogu politycznego oraz przyczynków. Parlamenty jednoizbowe, w liczbie 15, przesłały 290 uzasadnionych opinii oraz 1832 opinie w ramach dialogu politycznego i przyczynków. Jednak, co ciekawe, najbardziej aktywnymi parlamentami były jednoizbowy szwedzki Riksdag oraz jednoizbowa portugalska Assembleia da República (zob. wykres 3 i 4$)$.

Wykres 3. Ranking izb parlamentów narodowych pod względem liczby uzasadnionych opinii przesłanych do KE i PE (2010-2016)

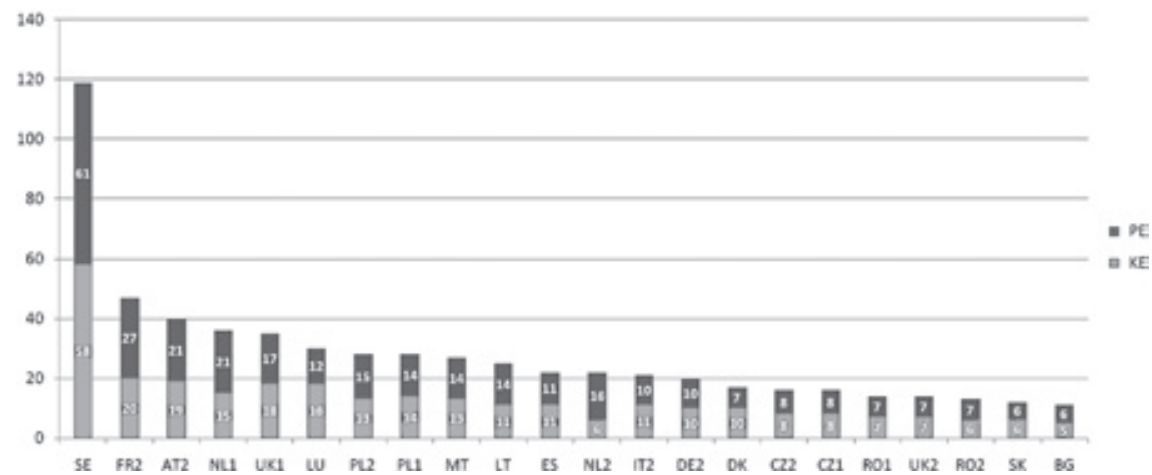

Źródło: opracowanie własne na podstawie: European Commission, Annual Reports on Relations...; European Commission, Annual Reports on Subsidiarity...; European Parliament, Annual Statistics for Subsidiarity...

15 European Commission, Annual Reports on Relations with National Parliaments, [online] https:// ec.europa.eu/info/annual-reports-relations-national-parliaments_en, 1 III 2018; European Commission, Annual Reports on Subsidiarity and Proportionality, [online] http://ec.europa.eu/dgs/secretariat_general/relations/relations_other/npo/subsidiarity_reports_en.htm, 1 III 2018; European Parliament, Annual Statistics for Subsidiarity Checks by National Parliaments, [online] http://www.europarl. europa.eu/relnatparl/en/about/subsidiarity.html, 1 III 2018. 
Wykres 4. Ranking izb parlamentów narodowych pod względem liczby opinii przesłanych w ramach dialogu politycznego do KE oraz jako przyczynki do PE (2010-2016)

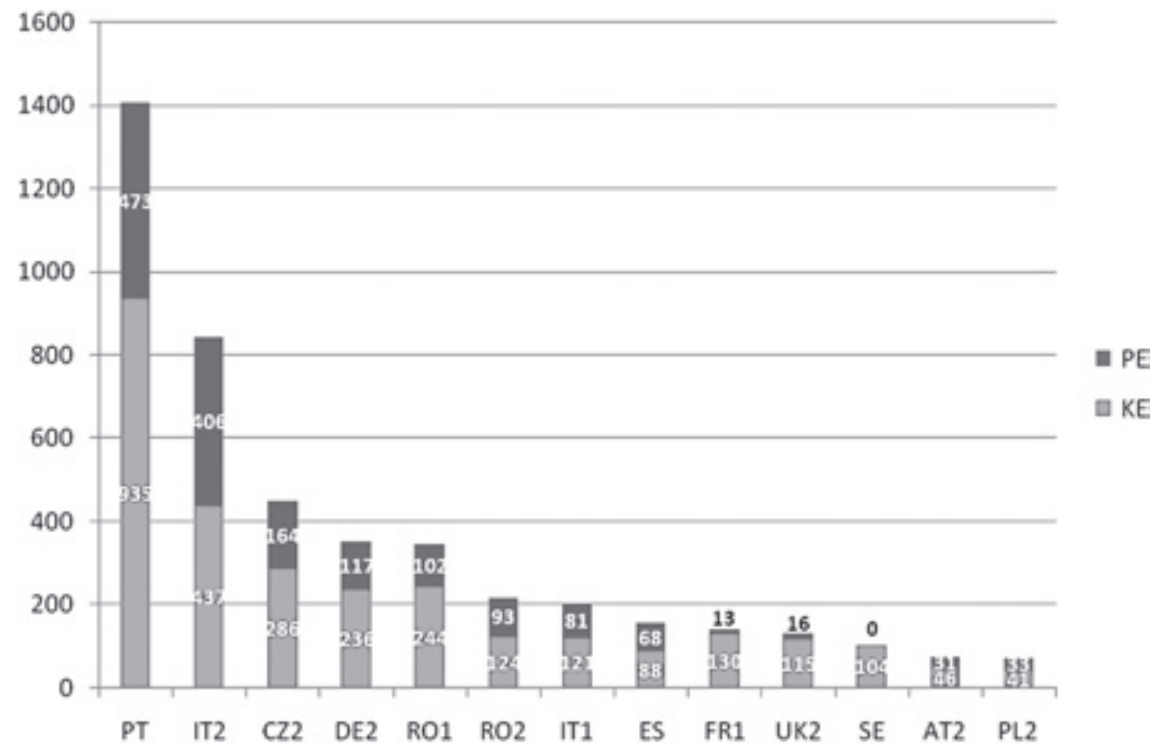

Źródło: opracowanie własne na podstawie: European Commission, Annual Reports on Relations...; European Commission, Annual Reports on Subsidiarity...; European Parliament, Annual Statistics for Subsidiarity...

W parlamentach dwuizbowych można było zaobserwować większą aktywność izby wyższej w zakresie EWS (zob. wykres 5). Izby wyższe z 13 parlamentów państw członkowskich w latach 2010-2016 zgłosiły 263 uzasadnione opinie do KE i PE, izby niższe - 163 opinie; dysproporcja ta jest jeszcze większa w przypadku dialogu politycznego i przyczynków. Zjawisko to wytłumaczyć można faktem, że 9 spośród 13 drugich izb parlamentów narodowych ma możliwość ograniczonego udziału w tworzeniu polityki krajowej w sprawach UE ${ }^{16}$. Dodatkowo w 8 z nich pozycja ustrojowa drugich izb jest asymetryczna względem izby niższej, co sprawia, że nie odgrywa ona pierwszoplanowej roli w procedurach ustawodawczych w kraju ${ }^{17}$. Podobnych ograniczeń Protokół nr 1 nie przewiduje w zakresie przekazywania parlamentom narodowym dokumentów unijnych. Częstsze wykorzystywanie przez izby wyższe uzasadnionych opinii oraz zgłaszanie PE i KE uwag o charakterze politycznym do projektów aktów ustawodawczych może więc kompensować mniejsze niż w przypadku izb niższych możliwości korzystania z funkcji europejskich.

16 A. Pudło, Rola drugich izb parlamentów państw cztonkowskich w sprawach Unii Europejskiej w świetle regulacji krajowych i unijnych, Warszawa 2011, s. 152.

17 J. Szymanek, Dwuizbowość parlamentu w europejskich systemach politycznych, „Studia Prawnicze” 2000, nr 3-4, s. 47; A. Pudło, Rola drugich izb..., s. 105-106. 
Wykres 5. Liczba uzasadnionych opinii oraz opinii w ramach dialogu politycznego z KE i przyczynków wysyłanych do PE przez poszczególne izby parlamentów dwuizbowych (2010-2016)

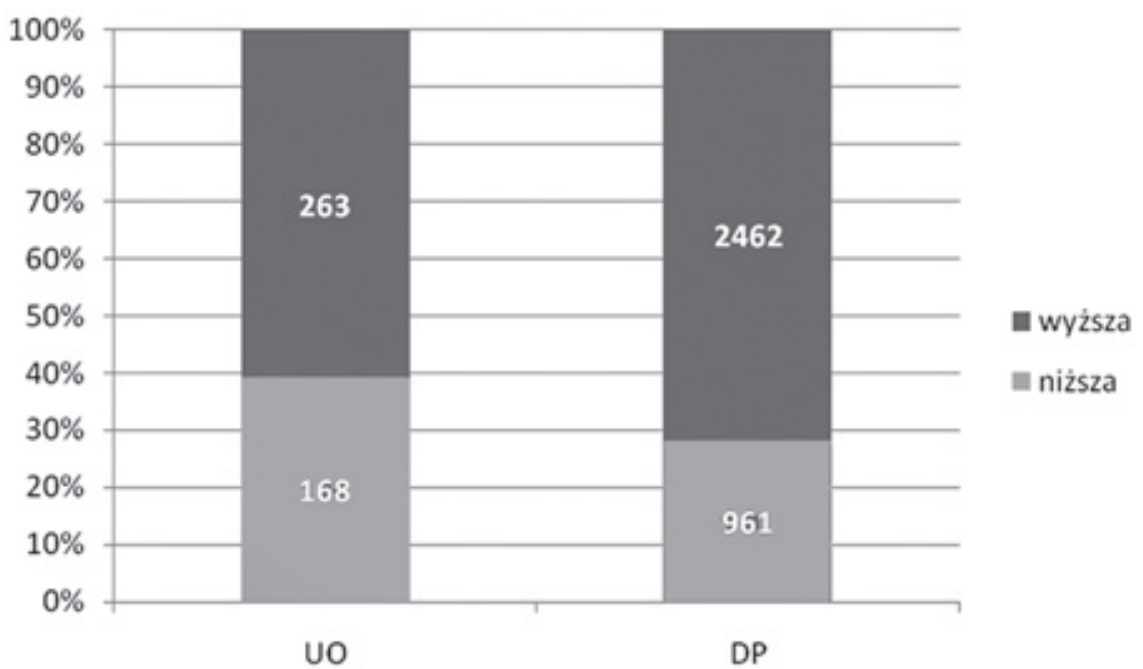

Źródło: opracowanie własne na podstawie: European Commission, Annual Reports on Relations...; European Commission, Annual Reports on Subsidiarity...; European Parliament, Annual Statistics for Subsidiarity...

Najwięcej uzasadnionych opinii przesyłanych do KE dotyczyło projektów aktów ustawodawczych z obszaru: rynku wewnętrznego (130 opinii), infrastruktury, transportu i komunikacji (49), kontroli granic i migracji (30), gospodarki i finansów (28), kwestii społecznych (26) oraz współpracy sądowej w sprawach karnych $(24)^{18}$. Uzasadnione opinie przesłane do PE przekazywane były odpowiednim komisjom, właściwym ze względu na przedmiot danego projektu aktu prawnego. Najwięcej opinii rozpatrzyły komisje ds.: gospodarczych i monetarnych (63), wolności obywatelskich, sprawiedliwości i spraw wewnętrznych (62), transportu i turystyki (58), ochrony środowiska naturalnego, zdrowia publicznego i bezpieczeństwa żywności (40), zatrudnienia i spraw socjalnych $(36)^{19}$.

Przedstawiając praktykę stosowania EWS, należy odnieść się do „żółtej” i „pomarańczowej kartki”, z którymi wiązano największe oczekiwania. Od momentu wejścia w życie traktatu z Lizbony procedura „pomarańczowej kartki” w ogóle nie została uruchomiona, zaś procedurę „żółtej kartki” wszczynano trzykrotnie ${ }^{20}$. Po raz pierwszy

18 Pozostałe obszary to: środowisko (22), rolnictwo (15), zdrowie (13), rynek spożywczy (11), współpraca sądowa w sprawach cywilnych (10), energetyka (10), polityka morska (9), normy, statystyka, wykorzystywanie danych publicznych itp. (5), nauka, badania, edukacja (3), polityka spójności (2), kultura (1), rybactwo i rybołówstwo (1).

19 Pozostałe komisje to: ds. rolnictwa i rozwoju wsi (30), ds. prawnych (27), ds. rynku wewnętrznego i ochrony konsumentów (23), ds. przemysłu, badań naukowych i energii (22), ds. praw kobiet i równouprawnienia (7), ds. kontroli budżetowej (1), ds. kultury i edukacji (1), ds. rybołówstwa (1), ds. rozwoju regionalnego (1).

20 Komisja Europejska, Sprawozdanie roczne za 2012 r. w sprawie pomocniczości i proporcjonalności, Bruksela, 30 VII 2013, COM(2013) 566 final, s. 7-9; Komisja Europejska, Sprawozdanie roczne za 2013 r. 
uczyniono to $\mathrm{w} 2012 \mathrm{r}$ r. wobec projektu rozporządzenia w sprawie wykonywania prawa do podejmowania działań zbiorowych w kontekście swobody przedsiębiorczości i swobody świadczenia usług (tzw. rozporządzenie Monti II). Udało się wówczas zebrać 19 głosów od 12 izb parlamentarnych i w rezultacie KE wycofała wniosek legislacyjny. Po raz drugi procedurę „żółtej kartki” zastosowano rok później, w odniesieniu do projektu rozporządzenia ustanawiającego Prokuraturę Europejską. Był to projekt z zakresu PWBiS, a więc zastosowanie miał obniżony próg liczby głosów izb parlamentarnych. Ostatecznie uzasadnione opinie zgłosiło $14 \mathrm{izb}$, co pozwoliło uzyskać łącznie 19 głosów. Decyzją KE wniosek legislacyjny nie został jednak wycofany ani zmieniony. KE utrzymała go także w trzecim przypadku zastosowania procedury „żółtej kartki”. W 2016 r. udało się zebrać najwięcej głosów od parlamentów państw członkowskich od momentu wprowadzenia EWS. Wobec projektu dyrektywy dotyczącej delegowania pracowników w ramach świadczenia usług zebrano 22 głosy od 14 izb parlamentarnych, głównie z krajów członkowskich z Europy Środkowo-Wschodniej, których interesów ten projekt dotyczył najmocniej.

Biorąc pod uwagę liczbę przyjmowanych aktów prawnych, trzy przypadki zastosowania procedury „żółtej kartki” w ciągu prawie ośmiu lat obowiązywania traktatu z Lizbony oraz jej efekty wskazują, że mechanizm ten nie wpływa w dużym stopniu na proces legislacyjny w UE. Warto jednak zauważyć - szczególnie w przypadku ostatniego z wniosków legislacyjnych dotyczących pracowników delegowanych - że EWS daje okazję do koordynowania stanowisk parlamentów narodowych na poziomie ponadnarodowym w przypadkach wrażliwych ze względu na interes krajowy. Można uznać to za ważne doświadczenie polityczne, którego parlamenty z reguły nie mogą zaznać na innych płaszczyznach współpracy międzynarodowej.

\section{PROPOZYCJE USPRAWNIENIA MECHANIZMU WCZESNEGO OSTRZEGANIA ORAZ REFORMY DIALOGU POLITYCZNEGO}

W badaniach przeprowadzonych przez Konferencję Komisji ds. Unijnych Parlamentów Unii Europejskiej (COSAC) ponad 63\% izb parlamentów narodowych stwierdziło, że procedura „żółtej kartki” wymaga poprawek ${ }^{21}$. Wśród najczęściej proponowanych usprawnień EWS pojawiały się dotyczące jakości oraz terminowości odpowiedzi udzielanych przez KE, a także ośmiotygodniowego terminu wydawania uzasadnionych opinii ${ }^{22}$. W ostatniej kwestii francuskie Assemblée nationale, szwedzki Riksdag, niderlandzka

w sprawie pomocniczości i proporcjonalności, Bruksela, 5 VIII 2014, COM(2014) 506 final, s. 15-16; Komisja Europejska, Sprawozdanie roczne za rok 2016 w sprawie pomocniczości i proporcjonalności, Bruksela, 30 VI 2017, COM(2017) 600 final, s. 15-17.

21 Sekretariat Konferencji Komisji do Spraw Unijnych Parlamentów Unii Europejskiej, Dwudziesty czwarty raport pótroczny: zmiany stosowanych $w$ Unii Europejskiej procedur i praktyk dotyczacych kontroli parlamentarnej, 4 XI 2015, s. 12, [online] http://oide.sejm.gov.pl/oide/images/files/international/raport_cosac_24.pdf, 20 III 2018.

22 Tamże, s. 12. 
Tweede Kamer oraz czeski Sénat zwróciły uwagę na uwzględnienie w dotychczasowym ośmiotygodniowym terminie przerw wakacyjnych. Pojawiły się też propozycje (m.in. ze strony cypryjskiej Vouli ton Antiprosopon) wydłużenia tego terminu o dwa tygodnie w przypadku rozpatrywania bardziej złożonych propozycji legislacyjnych. Wśród parlamentów narodowych powszechnie pojawiały się głosy o potrzebie zwiększenia koordynacji, współpracy i wymiany informacji między sobą. Postulat ten jest uzasadniony chociażby tym, że - jak wskazują parlamenty - wciąż brakuje im ujednoliconych kryteriów badania zasady pomocniczości czy formularzy wewnętrznych na potrzeby sporządzania uzasadnionych opinii ${ }^{23}$. Na te kwestie zwrócił uwagę także PE, który dodatkowo zasugerował, że wzmocnieniu współpracy między parlamentami przysłużyć mogłyby się adnotacje do każdego aktu ustawodawczego opublikowanego w Dzienniku Urzędowym UE. Wyszczególniałyby one te parlamenty narodowe, które udzieliły odpowiedzi, oraz te, które wyrazily wątpliwości dotyczące stosowania zasady pomocniczości ${ }^{24}$.

Ograniczenia procedur „żółtej” i „pomarańczowej kartki”, które uwidoczniły się po pierwszych kilku latach ich obowiązywania, skłoniły parlamenty narodowe do przedstawienia propozycji usprawnienia EWS. Na potrzebę innego spojrzenia na logikę tego mechanizmu wskazał włoski deputowany do PE Carlo Casini. W sprawozdaniu w sprawie stosunków między PE a parlamentami narodowymi z 27 marca 2014 r. pisał on: różne „uzasadnione opinie” powinny być interpretowane nie jako wskaźnik negatywny dotyczacy tego, czego UE nie powinna robic, lecz raczej jako pozytywna sugestia dotyczaca tego, co zrobić powinna ${ }^{25}$. Kilka miesięcy później ideę bardziej aktywnej roli uzasadnionych opinii przekuło w praktyczne propozycje zmian kilka parlamentów państw członkowskich.

Pomysł „zielonej kartki” (wzmocnionego dialogu politycznego), autorstwa m.in. brytyjskiej House of Lords, duńskiego Folketingu i holenderskiej Tweede Kamer, zakładał możliwość wnoszenia do KE propozycji inicjatyw ustawodawczych, w tym przeglądu i uchylania istniejących przepisów ${ }^{26}$. Kryterium zakwalifikowania opinii jako ,zielonej kartki” powinno być wniesienie jej w określonym terminie wraz z podpisami określonej liczby popierających ją izb parlamentarnych. Dodatkowo w styczniu 2015 r. House of Lords przedstawiła trzy propozycje zagadnień, których mogłyby dotyczyć pierwsze próby wzmocnionego dialogu politycznego. Były to: utylizacja odpadów spożywczych, opłaty bankowe w transakcjach transgranicznych oraz utworzenie Europejskiego Forum Biznesu ${ }^{27}$.

W kolejnych miesiącach zadanie uszczegółowienia koncepcji „zielonej kartki” oraz ewentualnych zmian w istniejącym mechanizmie EWS wzięła na siebie COSAC. W przeprowadzanych co pół roku ankietach izby parlamentów państw członkowskich

\footnotetext{
Tamże, s. 13-14.

Tamże, s. 13.
}

25 Parlament Europejski, Komisja Spraw Konstytucyjnych, Sprawozdanie w sprawie stosunków między Parlamentem Europejskim a parlamentami narodowymi (2013/2185(INI)). Sprawozdawca: Carlo Casini, 27 III 2014, s. 13, [online] http://www.europarl.europa.eu/sides/getDoc.do?pubRef=-//EP// TEXT+REPORT+A7-2014-0255+0+DOC+XML+V0//PL, 19 III 2018.

26 K. Borońska-Hryniewiecka, „Zielona kartka”: czas na rewizje zaangażowania parlamentów narodowych w politykę Unii Europejskiej, „Biuletyn Polskiego Instytut Spraw Międzynarodowych” 2015, nr 39. 
wyrażały swoje stanowisko dotyczące nowego pomysłu. Większość z nich (23 z 27) poparła pomysł wprowadzenia „zielonej kartki”. Niechętne parlamenty (włoska Camera dei Deputati, rumuński Senatul) zwróciły uwagę m.in. na ryzyko niezgodności z obowiązującymi traktatami i możliwość zachwiania równowagi instytucjonalnej w UE. Fińska Eduskunta wskazała zaś, że instytucjonalizacja rozwiązań pozatraktatowych może jeszcze bardziej skomplikować unijny proces decyzyjny. Niemiecki Bundestag zaznaczył z kolei, że nowa procedura powinna być zgodna ze stanowiskiem PE.

W drugiej ankiecie przesłanej przez COSAC do parlamentów jesienią 2015 r. 13 izb wskazało, że od momentu ostatniej ankiety przyjęły one oficjalne stanowiska w sprawie procedury „zielonej kartki”, w większości popierające tę koncepcję ${ }^{28}$. Jednocześnie w tym i kolejnych badaniach opinii izby parlamentów narodowych wyrazily swoje poglądy na temat tego, jak szczegółowa powinna być procedura wzmocnionego dialogu politycznego ${ }^{29}$. Spośród izb parlamentów, które nadesłały swoje odpowiedzi do COSAC, ok. 30\% opowiedziało się za tym, aby wymagany do uruchomienia procedury próg stanowił jedną trzecią głosów, a ok. $19 \%$ poparło próg wynoszący jedną czwartą. Jeżeli chodzi o okres, w którym swoje poparcie dla „zielonej kartki” mogły wyrazić pozostałe parlamenty, to $44 \%$ izb wskazało, że inicjujący parlament lub inicjująca izba powinny wyznaczać termin uczestnictwa w „zielonej karcie” według własnego uznania, zaś ok. 30\% opowiedziało się za tym, aby termin na ukończenie procedury „zielonej kartki” wyniósł od 16 tygodni do 6 miesięcy (wybór terminu powinien leżeć w gestii inicjującego parlamentu lub izby). Propozycje parlamentów dotyczyły także wprowadzenia możliwości wycofania poparcia dla „zielonej kartki". Około $90 \%$ izb opowiedziało się za tym, by rezygnacja była dozwolona na każdym etapie procedury. Prawie wszystkie parlamenty, które udzieliły odpowiedzi w ankietach (ok. 95\%), wskazały, że przekazywanie propozycji poprawek do oryginalnego tekstu przygotowanego przez inicjujący parlament (izbę) powinno być możliwe, a poprawki te winny być przedstawiane $\mathrm{w}$ terminie określonym przez inicjujący parlament (izbę).

W ankietach COSAC pytano także, jakie propozycje wniosków legislacyjnych parlamenty chciałyby zgłosić w ramach procedury „zielonej kartki”30. Brytyjska House of Lords wskazała na wniosek dotyczący rozwiązania problemu marnotrawienia żywności, który mógłby zawierać propozycje działań pozalegislacyjnych i kroków, które miałaby podjąć KE (np. opracowanie planu działania). Komisja ds. Unii Europejskiej duńskiego

28 Były to: litewski Seimas, cypryjska Izba Reprezentantów, czeski Senat, niderlandzka Izba Druga, duński Folketing i włoska Izba Deputowanych, Maltańska Izba Deputowanych, francuskie Zgromadzenie Narodowe, chorwacki Sabor, belgijska Izba Reprezentantów, włoski Senat Republiki, niderlandzka Izba Pierwsza oraz luksemburska Izba Deputowanych. Zob. Sekretariat Konferencji Komisji do Spraw Unijnych Parlamentów Unii Europejskiej, Dwudziesty czwarty raport pótroczny..., s. 6.

29 Tamże, s. 8-12; Sekretariat Konferencji Komisji do Spraw Unijnych Parlamentów Unii Europejskiej, Dwudziesty piąty raport pótroczny: zmiany stosowanych w Unii Europejskiej procedur i praktyk dotyczacych kontroli parlamentarnej, 18 V 2016, s. 12-14, [online] http://oide.sejm.gov.pl/oide/images/files/ international/raport_cosac_25.pdf, 20 III 2018.

30 Sekretariat Konferencji Komisji do Spraw Unijnych Parlamentów Unii Europejskiej, Dwudziesty trzeci raport pótroczny: zmiany stosowanych $w$ Unii Europejskiej procedur i praktyk dotyczacych kontroli parlamentarnej, 5 V 2015, s. 42-43, [online] http://oide.sejm.gov.pl/oide/images/files/international/raport_cosac_23.pdf, 20 III 2018. 
Folketingu zaproponowała wniosek dotyczący utworzenia Europejskiego Forum Gospodarczego. Łotewska Saeima przedstawiła pomysł dyrektywy w kwestii dostępu do wymiaru sprawiedliwości w sprawach związanych ze środowiskiem. Francuski Sénat wskazał zaś gotowość przedstawienia wniosków dotyczących unii energetycznej, agendy cyfrowej i walki z terroryzmem.

Swój pomysł House of Lords wcieliła w życie 22 lipca 2015 r., kiedy to wystąpiła z propozycją „zielonej kartki” dotyczącą rozwiązywania problemu marnotrawienia żywności. Podpisało ją 16 izb parlamentów narodowych ${ }^{31}$. Rok później, 11 lipca 2016 r., z drugą w historii propozycją ,zielonej kartki” wystąpiło wspólnie, z inicjatywy francuskiej Assemblée nationale, osiem izb parlamentów narodowych. Zwrócity się one do KE o przedłożenie wniosku ustawodawczego, wdrażającego zasady społecznej odpowiedzialności przedsiębiorstw na szczeblu europejskim, które miałyby zastosowanie do wszystkich przedsiębiorstw z siedzibą w UE oraz przewidywałyby dokładne zobowiązania i sankcje ${ }^{32}$.

\section{ZAKOŃCZENIE}

Dotychczasowa siedmioletnia udokumentowana praktyka stosowania mechanizmu wczesnego ostrzegania uprawnia do stwierdzenia, że instrumenty EWS, takie jak uzasadnione opinie oraz mechanizmy „żółtej” i „pomarańczowej kartki”, są mniej atrakcyjne niż bardziej elastyczne instrumenty, takie jak dialog polityczny z KE oraz przesyłanie opinii (tzw. przyczynków) do PE. Przyczyną takiego stanu rzeczy są trudności z zebraniem przez parlamenty wystarczającej liczby głosów wymaganych do uruchomienia tych procedur. Trudno się jednak zgodzić, że problemem jest za wysoki minimalny próg głosów (19, 14 lub zwykłej większości), do którego uzyskania obliguje traktat z Lizbony. Wszak parlamenty same proponowały podobne limity, pozwalające na uruchomienie „zielonej kartki”. Oznaczałoby to, że przy głosowaniu pozytywnym, a więc za poparciem jakiegoś wniosku, przyjęte progi nie prezentują się parlamentom jako nazbyt wygórowane. Wydaje się więc - co pokazały także ankiety COSAC - że problemy leżą raczej po stronie samych parlamentów; jest nim z pewnością także brak ujednoliconych kryteriów badania zasady pomocniczości oraz ugruntowanych wewnętrznych mechanizmów koordynacji i opracowywania uzasadnionych opinii.

31 Były to: bułgarskie Narodno sabranie, chorwacki Hrvatski sabor, cypryjski Vouli ton Antiprosopon, czeska Poslanecká sněmovna, francuskie Assemblée nationale i Sénat, węgierski Országgyűlés, włoski Senato della Repubblica, totewska Saeima, litewski Seimas, luksemburska Chambre des Députés, maltańska Kamra tad-Deputati, niderlandzka Tweede Kamer, portugalska Assembleia da República, słowacka Národná rada, brytyjska House of Lords. Zob. House of Lords European Union Committee, Food Waste: a Proposal by National Parliaments to the European Commission, 22 VII 2015, [online] https://www.parliament.uk/documents/lords-committees/eu-select/green-card/green-card-on-food-waste.pdf, 21 III 2018.

32 Były to: francuska Assemblée nationale, włoski Senato della Repubblica, łotewska Saeima, litewski Seimas, niderlandzka Tweede Kamer, portugalska Assembleia da República, słowacka Národná rada i House of Lords Zjednoczonego Królestwa. Dnia 26 VII 2016 r. dołączył do nich grecki Vouli ton Ellinon. Zob. Komisja Europejska, Sprawozdanie roczne za rok 2016 na temat stosunków między Komisja Europejskq a parlamentami narodowymi, Bruksela, 30 VI 2017, COM(2017) 601 final, s. 10-11. 


\section{BIBLIOGRAFIA}

Borońska-Hryniewiecka K., „Zielona kartka”: czas na rewizję zaangażowania parlamentów narodowych w politykę Unii Europejskiej, „Biuletyn Polskiego Instytut Spraw Międzynarodowych" 2015, nr 39.

Cooper I., $A$ "Virtual Third Chamber" for the European Union? National Parliaments after the Treaty of Lisbon, „West European Politics” 2012, vol. 35, nr 3, [online] https://doi.org/10. 1080/01402382.2012.665735.

Dulak M., Legitymizacja polskiej polityki europejskiej. Analiza systemowa, Kraków 2017.

European Commission, Annex to the Communication from the Commission to the European Parliament, the Council, the European Economic and Social Committee and the Committee of the Regions. Commission Work Programme 2013, Strasbourg, 29 VI 2012, COM(2012) 629 final.

European Commission, Annexes to the Communication from the Commission to the European Parliament, the Council, the European Economic and Social Committee and the Committee of the Regions. Commission Work Programme 2014, Brussels, 22 X 2013, COM(2013) 739 final.

European Commission, Annex to the Communication from the Commission to the European Parliament, the Council, the European Economic and Social Committee and the Committee of the Regions. Commission Work Programme 2015. A New Start, Strasbourg, 8 I 2015, $\operatorname{COM}(2014) 910$ final.

European Commission, Annual Reports on Relations with National Parliaments, [online] https://ec.europa.eu/info/annual-reports-relations-national-parliaments_en.

European Commission, Annual Reports on Subsidiarity and Proportionality, [online] http:// ec.europa.eu/dgs/secretariat_general/relations/relations_other/npo/subsidiarity_reports_ en.htm.

European Parliament, Annual Statistics for Subsidiarity Checks by National Parliaments, [online] http://www.europarl.europa.eu/relnatparl/en/about/subsidiarity.html.

Grzelak A., Łacny J., Kontrola przestrzegania unijnej zasady pomocniczości przez parlamenty narodowe - pierwsze doświadczenia, „Zeszyty Prawnicze Biura Analiz Sejmowych” 2011, nr 4.

House of Lords European Union Committee, Food Waste: a Proposal by National Parliaments to the European Commission, 22 VII 2015, [online] https://www.parliament.uk/documents/ lords-committees/eu-select/green-card/green-card-on-food-waste.pdf.

Komisja Europejska, Sprawozdanie roczne za 2013 r. w sprawie pomocniczości i proporcjonalności, Bruksela, 5 VIII 2014, COM(2014) 506 final.

Komisja Europejska, Sprawozdanie roczne za rok 2016 na temat stosunków między Komisją Europejska a parlamentami narodowymi, Bruksela, 30 VI 2017, COM(2017) 601 final.

Komisja Europejska, Sprawozdanie roczne za rok 2016 w sprawie pomocniczości i proporcjonalności, Bruksela, 30 VI 2017, COM(2017) 600 final.

Komunikat Komisji do Rady Europejskiej. Plan osiagnięcia wyników dla Europy z myśla o obywatelach, Bruksela, 10 V 2006, COM(2006) 211 final.

Mik C., Pozycja prawna parlamentów narodowych w Unii Europejskiej w świetle Traktatu z Lizbony, ,Ruch Prawniczy, Ekonomiczny i Socjologiczny” 2010, z. 2. 
Parlament Europejski, Komisja Spraw Konstytucyjnych, Sprawozdanie w sprawie stosunków między Parlamentem Europejskim a parlamentami narodowymi (2013/2185(INI)). Sprawozdawca: Carlo Casini, 27 III 2014, [online] http://www.europarl.europa.eu/sides/getDoc. do?pubRef=-//EP//TEXT+REPORT+A7-2014-0255+0+DOC+XML+V0//PL.

Pudło A., Rola drugich izb parlamentów państw cztonkowskich w sprawach Unii Europejskiej $w$ świetle regulacji krajowych i unijnych, Warszawa 2011.

Sekretariat Konferencji Komisji do Spraw Unijnych Parlamentów Unii Europejskiej, Dwudziesty trzeci raport pótroczny: zmiany stosowanych $w$ Unii Europejskiejprocedur i praktyk dotyczacych kontroli parlamentarnej, 5 V 2015, [online] http://oide.sejm.gov.pl/oide/images/files/ international/raport_cosac_23.pdf.

Sekretariat Konferencji Komisji do Spraw Unijnych Parlamentów Unii Europejskiej, Dwudziesty czwarty raport pótroczny: zmiany stosowanych $w$ Unii Europejskiej procedur i praktyk dotyczacych kontroli parlamentarnej, 4 XI 2015, [online] http://oide.sejm.gov.pl/oide/images/ files/international/raport_cosac_24.pdf.

Sekretariat Konferencji Komisji do Spraw Unijnych Parlamentów Unii Europejskiej, Dwudziesty piąty raport pótroczny: zmiany stosowanych $w$ Unii Europejskiej procedur i praktyk dotyczacych kontroli parlamentarnej, 18 V 2016, [online] http://oide.sejm.gov.pl/oide/images/ files/international/raport_cosac_25.pdf.

Sprawozdanie roczne za 2012 r. w sprawie pomocniczości i proporcjonalności, Bruksela, 30 VII 2013, $\operatorname{COM}(2013) 566$ final.

Statystyki dotyczące aktów prawnych, [online] http://eur-lex.europa.eu/statistics/legislative-acts-statistics.html.

Szymanek J., Dwuizbowość parlamentu w europejskich systemach politycznych, „Studia Prawnicze” 2000, nr 3-4.

Traktat ustanawiajacy Konstytucję dla Europy, Dz.U. UE 2004, C 310/01.

Traktat z Lizbony zmieniajacy Traktat o Unii Europejskiej i Traktat ustanawiajacy Wspólnotę Europejska, Dz.U. UE 2007, C 306.

Węc J.J., Spór o ksztatt instytucjonalny Wspólnot Europejskich i Unii Europejskiej 1950-2005. Między idea ponadnarodowości a wspótpraca międzyrządową. Analiza politologiczna, Kraków 2006.

Węc J.J., Traktat lizboński. Polityczne aspekty reformy ustrojowej Unii Europejskiej w latach 2007-2009, Kraków 2011.

Witkowska M., Parlamenty narodowe jako podmioty integracji europejskiej z perspektywy reformowania Unii Europejskiej, [w:] M. Witkowska [i in.], Podmioty integracji europejskiej zperspektywy reformowania Unii Europejskiej, Warszawa 2017.

Witkowska M., The Use of the Concept of Policy Networks in the Study of Relations Between National Parliaments and the EU Institutions, „Przegląd Europejski” 2016, nr 4.

Dr Michał DULAK, doktor nauk społecznych w zakresie nauk o polityce. Asystent w Katedrze Studiów nad Procesami Integracyjnymi w Instytucie Nauk Politycznych i Stosunków Międzynarodowych UJ, członek Polskiego Towarzystwa Studiów Europejskich. 